\title{
The evaluation of 2.3-diazepine influence on tissue respiration of the liver and its exocrine function in rats with a rotenone model of Parkinson's disease
}

\author{
V. P. Khilya ${ }^{2}$, I. P. Yanchuk ${ }^{1}$, L. Ya. Shtanova ${ }^{1,2}$, S. P. Veselsky ${ }^{1}$, T. V. Vovkun ${ }^{2}$, \\ O. V. Tsymbalyuk ${ }^{1}$, V. S. Moskvina ${ }^{2}$, O. V. Shablykina ${ }^{2}$, S. L. Bogza ${ }^{2}$ \\ ${ }^{1}$ Institute of High Technologies, Taras Shevchenko National University of Kyiv \\ 2, korp.5, Pr. Akademika Hlushkova, Kyiv, Ukraine, 03022 \\ 2 Taras Shevchenko National University of Kyiv \\ 64, Volodymyrska Str., Kyiv, Ukraine, 01601 \\ e-mail: shtanova@ukr.net
}

Parkinson's disease (PD) is a progressive neurodegenerative disorder, characterized by the loss of dopaminergic neurons in the substantia nigra pars compacta. The causes of PD are not fully understood; however, increasing evidence implicates disturbed respiratory function of the mitochondria and a lack of energy in cells. Aim. To study the effects of 2.3-diazepine (2.3-DP), a new derivative of benzodiazepine, on liver tissue respiration (LTR) and energy dependent processes of bile and bile acids (BAs) production in a rat model of PD. Methods. PD was induced by intraperitoneal injections of rotenone (ROT). LTR (the intensity of the oxygen uptake) was assessed using the polarograph LP-9 (Czech Republic). Secreted bile was collected during 1 hour of the experiment through the polyethylene catheter inserted into the common bile duct. BAs were separated by the method of thin layer chromatography. Results. ROT diminished the index of liver oxygen consumption by $34 \%(\mathrm{p}<0.001)$, reduced bile flow by $33.8 \%(\mathrm{p}<0.001)$ and disturbed the conjugation of cholic acid with amino acids taurine and glycine reducing the index of conjugation by $29.2 \%(\mathrm{p}<0.001)$. ROT also increased by $25.6 \%(\mathrm{p}<0.001)$ the part of acidic pathway in the biosynthesis of BAs. The application of 2.3-DP results in full or partial recovery of LTR, bile flow, concentrations of BAs and their ratio in the bile of rats with PD. Conclusion. 2.3-DP markedly affected function of the liver parenchyma in a rat model of PD. This drug changed the intensity of LTR, bile flow and notably modified bile chemical compositions.

Ke y w o r d s: Parkinson's disease, 2.3-diazepine, tissue respiration, bile, bile acids.

C 2019 V. P. Khilya et al.; Published by the Institute of Molecular Biology and Genetics, NAS of Ukraine on behalf of Biopolymers and Cell. This is an Open Access article distributed under the terms of the Creative Commons Attribution License (http://creativecommons.org/licenses/by/4.0/), which permits unrestricted reuse, distribution, and reproduction in any medium, provided the original work is properly cited 


\section{Introduction}

Parkinson's disease (PD) is a progressive neurodegenerative disorder, characterized by the selective loss of dopaminergic neurons in nigra pars compacta of the midbrain leading to a significant reduction in dopamine levels in the striatum [1]. The factors causing selective neuronal cell death have not been clearly defined. To date, more than 15 genes have been identified which are associated with the hereditary forms of primary parkinsonism. The most studied PARK $1 \alpha$-synuclein plays an important role in synaptic vesicular transport and storage of neurotransmitters. Mutations (hereditary or due to the effects of exogenous neurotoxic factors) in the $\alpha$-synuclein gene lead to a change in the structure of the protein, its accumulation in the neuron and aggregation with the formation of Levi's bodies. Currently, $\alpha$-synuclein is considered as a key molecular marker of pathology of neurons and modulation of neurodegeneration of Parkinson's type [2]. Numerous studies suggest that an inhibition of mitochondrial complex I and a mitochondrial dysfunction leading to respiration disorder and energy deficit in the neurons might play an important role in neurodegeneration during progression of PD [3]. The cardinal manifestation of PD is severe abnormalities in motor function, namely rigidity, tremor in rest, bradykinesia, and the loss of postural reflexes as well as non-motor features $[1,4]$. Previous studies have shown that in PD, altered metabolic pathways may be associated with the exchange of certain compounds, in particular bile acids (BAs) [5]. Rotenone (ROT), an inhibitor of mitochondrial complex I, is usually used to reproduce the pathological features of PD in animal mo- dels $[6,7]$. The modeling of PD in rats by systemic administration of ROT revealed the symptoms similar to human pathology, namely nigrostrial degeneration and dysfunction of mitochondria [8]. Nowadays, pharmacological treatment of PD is performed by dopamine and levodopa (Ldopa) agonists. Dopamine agonists are the medicines that activate the dopamine receptor. They mimic or copy the function of dopamine in the brain but cause several serious undesirable effects, including nausea, vomiting, hypotension, and, in the long run, motor complications [9]. In this context, the drugs with the ability to modulate mitochondrial dynamics, function and biogenesis may have important clinical applications in the future treatment of PD. L.A. Fonseca et al. showed that benzodiazepine- derivative substances protect the neuronal mitochondria against ROT-induced damage in rats model of PD [10]. Ukrainian scientists have developed the chemical compounds of the class of 2.3-benzodiazepines, which are characterized by the activity in relation to CNS. The clinical success of tofizopam, one of these drugs, initiated further researches in order to obtain new derivatives of 2.3-benzodiazepine. As an inhibitor of the $\gamma$-secretase enzyme, which plays an important role in the investigation of Alzheimer's disease (AD), a derivative of the 2.3-benzodiazepine1.4-dione containing the diamond fragment 1.106 was proposed [11]. In the late 90s of the last century the first publications appeared devoted to the biological activity of condensed 2.3-benzodiazepines containing annelated heterocycles in the position of 3-4. Thus, the derivatives of triazolo [4.5-c] imidazo [1.2-c] 
[2.3] diazepine 1.104 showed a high anticonvulsant activity of the Talampanel drug.

The liver is an organ with intense metabolism and in a healthy person, it consumes about $20 \%$ of the total amount of oxygen in the body [12]. In turn, LTR is provided by mitochondria. The functioning of the mitochondria in neurons and hepatocytes is similar, therefore it was reasonable to establish the involvement of hepatocyte mitochondria in this pathology. The oxygen-dependent biosynthetic processes in the liver are closely related to the energy metabolism. Consequently, the consumption of oxygen by the liver may additionally indicates the functional status of the mitochondria.

The present study therefore was aimed to investigate: 1) the features of liver function in rats with ROT-induced $\mathrm{PD}$, in particular, tissue respiration of this organ, the rate of bile flow, as well as the biliary content of BAs, the synthesis of which directly depends on the state of energy metabolism in hepatocytes; 2) the effect of the synthetic agent of 2.3-DP on the parameters of LTR, the rate of bile secretion and the content and ratio of BAs in the bile of rats with experimental ROT model of PD.

\section{Materials and Methods}

Compounds and reagents. ROT, dimethyl sulfoxide (DMSO) and urethane were purchased from Sigma (St. Louis, MO, USA). Thiopentalum natrium was produced in Ukraine (OAO "Kyivmedpreparat").

Elemental analysis of 2.3-DP was performed in the analytical laboratory of V.P. Kukhar Institute of Bioorganic Chemistry and Petrochemistry, NAS of Ukraine, Kyiv, Ukraine: (E)-4-(4-Hydroxy-3-methylphenyl)$2 H$-benzo[ $d][1.2]$ diazepin-1 $(5 H)$-one

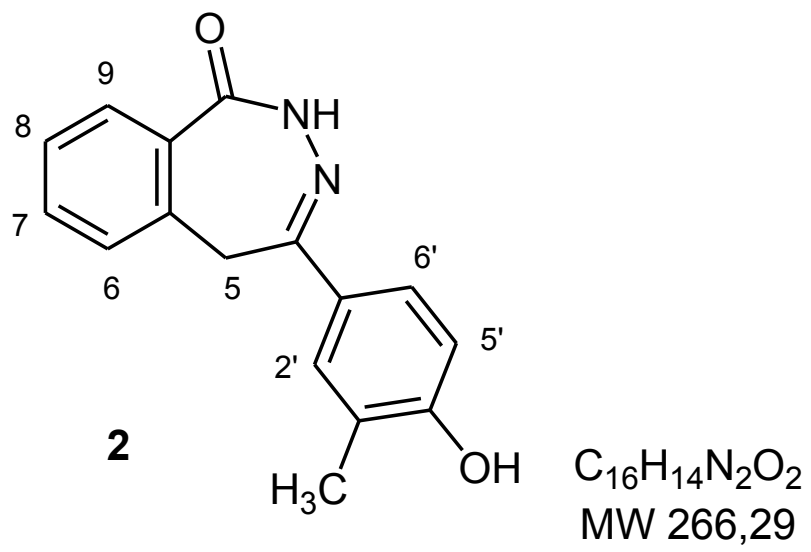

slowly dissolved, the conversion was controlled by TLC). The resulting solution of product 2 was evaporated using a rotary evaporator to half-volume and cooled. The crystal solid was separated by filtration and recrystallized from isopropyl alcohol. Yield $85 \%$. Mp $256-258{ }^{\circ} \mathrm{C}$. 
${ }^{1} \mathrm{H},{ }^{13} \mathrm{C}$ NMR spectra were recorded at Bruker Avance DRX500 NMR operating at $500 \mathrm{MHz}$ frequency for ${ }^{1} \mathrm{H}$ and $125 \mathrm{MHz}$ for ${ }^{13} \mathrm{C}$ experiments. NMR chemical shifs are reported in ppm, in the $\mathrm{d}$ scale and are referenced using TMS as internal standard. LC-MS data were acquired on Agilent 1100 HPLC system equipped with diode matrix and Agilent LC/ MSD SL mass-selective detector, with chemical ionization at atmospheric pressure (APCI).

${ }^{1} \mathrm{H}$ NMR $\left(500 \mathrm{MHz}, \mathrm{DMSO}-d_{6}, \delta\right.$, ppm, $J$, $\mathrm{Hz}): 2.14$ (3H, s, $\left.\mathrm{CH}_{3}-3 \phi\right), 3.99\left(2 \mathrm{H}, \mathrm{s}, \mathrm{CH}_{2}-5\right)$, $6.83(1 \mathrm{H}, \mathrm{d}, J=8.4, \mathrm{H}-5 \varnothing), 7.38(1 \mathrm{H}, \mathrm{t}, J=$ 7.3, H-8), 7.48-7.56 (2H, m, H-6,7), 7.62 (1H, br. d, $J=8.3, \mathrm{H}-6 \varnothing), 7.67$ (1H, s, H-2ф), 7.78 (1H, d, $J=7.6, \mathrm{H}-9), 9.83$ (1H, br. s, OH), $11.01(1 \mathrm{H}, \mathrm{NH})$.

${ }^{13} \mathrm{C}$ NMR (125 MHz, DMSO- $\left.d_{6}, \delta, \mathrm{ppm}\right)$ : $16.5,34.3,115.1,124.8,126.0,126.5,127.7$, $127.8,129.8,130.1,132.6,133.3,138.4,158.2$, 160.2, 167.2 .

LCMS, $m / z: 267[\mathrm{M}+1]^{+}$.

Found, \%: C, 72.24; H, 5.26; N, 10.53. Calc. for $\mathrm{C}_{16} \mathrm{H}_{14} \mathrm{~N}_{2} \mathrm{O}_{2}, \%$ : C, 72.16; H, 5.30; N, 10.52 .

Experimental animals. Study has been done in acute experiments on 60 male mature Wistar rats (obtained from Institute of Toxicology, Academy of Medical Sciences of Ukraine (Kyiv, Ukraine)), weighing 230-270 g. The animals were housed under standard conditions of humidity (55-60\%), in a temperature-controlled environment $\left(22 \pm 2{ }^{\circ} \mathrm{C}\right)$ with a $12 \mathrm{~h}$ light/dark cycle, with unlimited access to filtered water and commercial food throughout the experimental period. Animal housing care and the application of experimental procedures were in accordance with the existing international requirements and norms of humane attitude towards animals (Strasbourg, 1986, Law of Ukraine dated February 21, 2006, No. 3447-IV) and to the decision held by Biological Ethics Committee, Faculty of Biology, National Taras Schevchenko University of Kyiv (protocol No. 3 from April 9, 2009). This work has been done in accordance with Declaration of Helsinki (World medical assembly, 1964), Declaration of Principles on Tolerance (28th session of UNESCO, 1995), Universal Declaration on Bioethics and Human Rights related to introduction of new biomedical technologies, accepted in 1997 in the city of Oviedo (Spain) and signed by parliament of Ukraine in 2002, Law of Ukraine No. 3447 IV "About animals protection from brutal behavior".

Experimental design. Rats were injected with either ROT (2.0 mg/kg, intraperitoneally (i.p.)) suspended in sunflower oil $(1 \mathrm{ml} / \mathrm{kg}$ ) (ROT vehicle) or vehicle alone [13], daily for 28 consecutive days (from 10:00 a.m to 12:00 a.m.). After one week, the rats were randomly divided into six groups: (1) control group $(n=10)$, rats received an injection of sunflower oil $(1 \mathrm{ml} / \mathrm{kg}$ of body weight) that did not include ROT; (2) ROT group $(\mathrm{n}=9)$, ROT (2.0 mg/kg); (3) $\mathrm{ROT}+1 \%$ solution of DMSO group $(\mathrm{n}=8)$, ROT (2.0 mg/kg)+1 \% DMSO (1 ml/kg); (4) ROT+2.3-DP group $(\mathrm{n}=8)$, ROT $(2.0 \mathrm{mg} /$ $\mathrm{kg})+2.3-\mathrm{DP}(0,5 \mathrm{mg} / \mathrm{kg})$; (5) ROT+ 2.3-DP group $(\mathrm{n}=8)$, ROT $(2.0 \mathrm{mg} / \mathrm{kg})+2.3-\mathrm{DP}(1,0 \mathrm{mg} /$ $\mathrm{kg})$; (6) $\mathrm{ROT}+2.3-\mathrm{DP}$ group $(\mathrm{n}=8)$, ROT $(2.0 \mathrm{mg} / \mathrm{kg})+2.3-\mathrm{DP}(2.0 \mathrm{mg} / \mathrm{kg})$. Immediately before use, 2.3-DP was freshly suspended in a $1 \%$ DMSO solution. 2.3-DP $(0.5,1.0$ and $2.0 \mathrm{mg} / \mathrm{kg}$ ) or $1 \%$ DMSO ( $1 \mathrm{ml} / \mathrm{kg})$, were administrated daily, i.p. as a single dose, for 28 days, starting immediately after the last injection of ROT. The dose had been determined 
based on the lowest dose of other neuroprotective factors shown to be effective. During the experimental study period, animals from each group were weighed every seven days.

Behavioral Analysis. In the ROT-treated groups, rat fur became yellow and dirty; the rats showed reduced and slow movement, tremor, rigor and an unstable gait, which were identified as PD-like symptoms [13].

Locomotor Activity. The open-field test can be used to evaluate the spontaneous activity of rats. Twenty nine days following treatment rats were placed in an open field square box (100 cm long, $100 \mathrm{~cm}$ wide, and $40 \mathrm{~cm}$ high), and the test area is well illuminated. The experiment was carried out in a quiet environment. Rats were video-recorded (Fotocam, Canon) for $6 \mathrm{~min}, 1 \mathrm{~min}$ for habituation and $5 \mathrm{~min}$ for behavioral analyzes. The animal was placed into the center of the bottom of the box and turn on the camera to observe for $5 \mathrm{~min}$. Two motor parameters were quantified throughout this test: locomotion frequency (number of squares crossings, defined as the number of quadrant crossings with the four paws) and rearing frequency (times the animal rise for at least $2 \mathrm{~s}$ on their rear paws in the air or against the walls). Before the test, $70 \%$ ethanol was used to thoroughly wipe the inner wall and bottom surface of the box, so as not to affect the results of the next test. Replace the animals and continue the experiment [14].

Study of LTR. The intensity of oxygen absorption by the liver tissues was assessed by the rate of decrease in $\mathrm{pO}_{2}$ in the liver parenchyma with half a minute occlusion of the portal vein and the hepatic artery. Before the experiment, the rats were anesthetized with urethane $(1 \mathrm{~g} / \mathrm{kg}, 1 \mathrm{ml} / \mathrm{kg}$, intraperitoneally (i.p.)). Oxygen tension $\left(\mathrm{pO}_{2}\right)$ in the liver parenchyma was recorded using an LP-9 polarograph (Czech Republic). An open platinum microelectrode in glass insulation $(\mathrm{d}=0.3 \mathrm{~mm})$ with an operating voltage of $0.65 \mathrm{~V}$ was used as an indicator. A standard calomel electrode was used as a reference electrode. Several platinum electrodes were inserted into the liver, and the electrical signals from them were sent to the polarograph. To calculate the level of $\mathrm{pO}_{2}$ in the liver tissue, the method of the electrodes calibration in an environment with a known level of $\mathrm{pO}_{2}$ was applied [15]. $\mathrm{pO}_{2}$ in the liver was calculated according to the equation: $\mathrm{pO}_{2}=\mathrm{pO}_{2} \mathrm{~atm} \cdot \mathrm{Ae} \cdot \mathrm{Se} /(\mathrm{Ac} \cdot \mathrm{Sc})$, where: $\mathrm{pO}_{2} \mathrm{~atm}$ is the oxygen tension in a calibrated saline solution, balanced by an atmospheric pressure of $\mathrm{O}_{2}-150 \mathrm{~mm} \mathrm{Hg}$; Ac, Ae is the amplitude of the calibration and experimental signals (in $\mathrm{mm}$ of record); $\mathrm{Sc}$ and $\mathrm{Se}$ are the sensitivity of the polarograph scales during calibration and experiment. The rate of oxygen consumption by the liver tissue was determined by the curve of the drop in $\mathrm{pO}_{2}$ during asphyxia of the animal or occlusion of the afferent liver vessels [16]. The coefficient of oxygen consumption by the liver was calculated from this curve: $\mathrm{K}=\lg \left(\mathrm{I}_{1} / \mathrm{I}_{2}\right) / / 0,43 \cdot\left(\mathrm{t}_{2}-\mathrm{t}_{1}\right)$, where: $I_{1}$ and $I_{2}$ are the polarogram current values corresponding to $\mathrm{pO}_{2}$ at times $\mathrm{t}_{1}$ and $\mathrm{t}_{2}$ from the onset of asphyxia or occlusion of the liver afferent vessels. The coefficient $\mathrm{K}$ was determined in the interval from the 10th to the 30th second of asphyxia or vascular occlusion.

Determination of the bile flow and the bile concentration of different BAs. Every rat was anesthetized with thiopentalum natrium (4 mg/100 g rat b.w., i.p.). Common bile duct was cannulated with polyethylene catheters and 
secreted bile was collected every 30 minutes during 1 hour of the experiment by micropipette connected to cannula located in the bile duct. Bile flow was calculated by $\mu \mathrm{l} / \mathrm{g}$ of rat body weight. All manipulations were performed after stabilization of the bile flow (30 minutes).

Free and conjugated BAs were divided by thin layer chromatography method [17]. For this purpose, $0.1 \mathrm{ml}$ of bile was added to $1.9 \mathrm{ml}$ of cold, extracted mixture of ethanol and acetone $(1: 3)$. Samples were kept cool $\left(-10\right.$ to $\left.0^{\circ} \mathrm{C}\right)$ in an ice chamber for 25-30 minutes and then centrifuged for 10-12 minutes at 3000-4000 r.p.m. The extracts were then poured in conoid glass test tubes and dried at $37-40^{\circ} \mathrm{C}$ to get dry remainders. Dry remainders were dissolved in $50-100 \mu$ of ethanol-water mixture (6:4). 5-10 $\mu \mathrm{l}$ of samples were inflicted on the preliminary washed and marked chromatography plates $(15 \times 15 \mathrm{~cm}$, silica gel plates on aluminium back, Kavalier, Czech). Free and conjugated BAs deviation was carried out in the system containing amyl ester acetic acid, toluole, butanole, acetic acid and water (3:1:1:3:1, respectively), in glass chromatography chambers. Chromatograms were dyed after five times sprinkling from a glass fine-disperser pulveriser with the dye stuff ( $15 \mathrm{ml}$ icy acetic acid, 1 g phosphomolybdic acid, $1 \mathrm{ml}$ sulphuric acid and $5 \mathrm{ml}$ of $50 \%$ trichloroacetic acid solution). Chromatograms were put at $60-70^{\circ} \mathrm{C}$ during 5 minutes. Quantitative determination of BA content was performed by densitometer GP-920 (Shimadzu, Japan) under reflected light ( $\lambda 620$ $\mathrm{nm})$. This method allowed dividing mixture of BAs into following fractions: TCA, TCDCA+TDCA, GCA, GCDCA+GDCA, CA, CDCA+DCA. BAs content was calculated by $\mathrm{mg}$ per $100 \mathrm{ml}$ of bile $(\mathrm{mg} \%)$.
Statistical analysis. The results were assessed by: the parametric one-way ANOVA method and also in combination with the Tukey test for pairwise comparison and $p$ values less than 0.05 were considered significant; the nonparametric Kruskal-Wallis ANOVA method and also in combination with the Mann-Whitney test for pairwise comparison with Bonferroni correction and $p$ values less than 0.01 were considered significant. Statistical analysis was performed by Origin Pro 8.0, and the charts were drawn by Excel software.

Results. The present results revealed a significant decrease in rearing frequency (by $71 \%$, $\mathrm{p}<0.001$ ) and in locomotion frequency (by $92 \%$, $\mathrm{p}<0.001)$ in ROT group as compared to the control group. 2.3-DP treatment improved behavioral performance of rats with PD (Fig. 1, 2).

The current data revealed that during 56 days of the experiment in the control group of rats, body weight increased by $47 \%$ compared to baseline. In the ROT+DMSO group for the same period of time, the weight gain was only $19.1 \%(p<0.001)$. In contrast to the previous group, the use of 2,3-DP in doses of 0.5 and $1.0 \mathrm{mg} / \mathrm{kg}$ improved the weight gain of rats poisoned with ROT by $30.8 \%(\mathrm{p}<0.001)$ and $23 \%(\mathrm{p}<0.001)$, respectively (Fig. 3$)$.

The administration of ROT to rats caused a significant inhibition of LTR, as evidenced by a decrease in the oxygen consumption (K) compared with the control group by $34 \%$, $\mathrm{p}<0.001$ (Table 1). In rats with a ROT model of PD which were treated with $1 \%$ DMSO solution during 28 days, LTR recovered up to $73.4 \%$ of control level whereas in animals treated with 2.3-DP at doses of 0.5 and $1 \mathrm{mg} /$ $\mathrm{kg}$, LTR was restored to control levels $(\mathrm{K}=$ $1.96 \pm 0.15$ and $1.98 \pm 0.17$, respectively). 

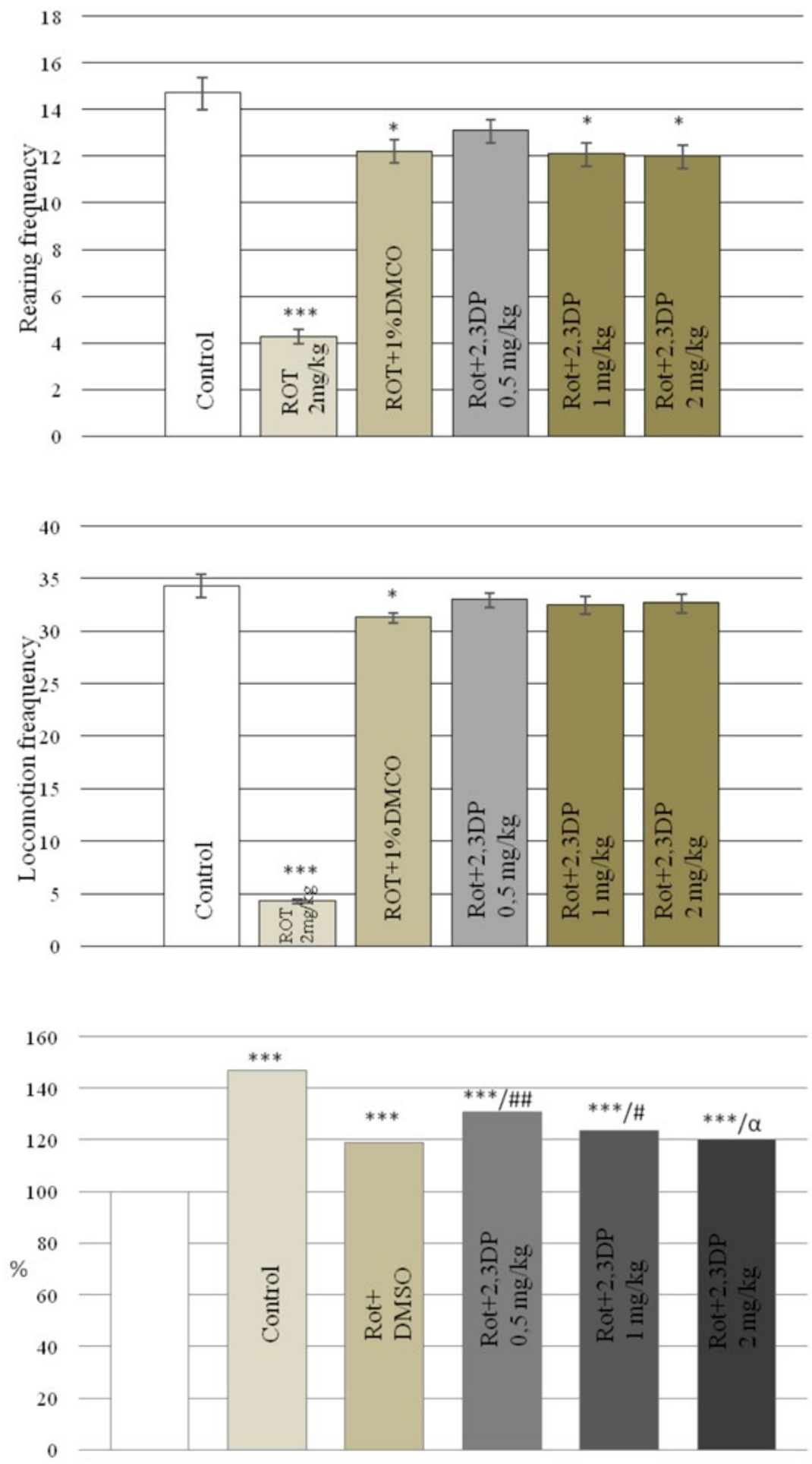

Fig. 1. Change in rearing frequency in rats with ROT-induced PD treated with 2.3-DP (open field test was used). The data are presented as the means \pm S.E.M. * ${ }^{*} \mathrm{p}<0.05, * * *$ $\mathrm{p}<0.001$ versus control group.

Fig. 2. The effect of 2.3-DP treatment on the locomotion frequency in rats with ROT-induced PD (open field test was used). The data are presented as the means \pm S.E.M. ${ }^{*}$ $\mathrm{p}<0.05, * * *-\mathrm{p}<0.001$ versus control group.

Fig. 3. Effects of 2.3-DP treatment on the weight gain in ROT-poisoned rats. $* * *-\mathrm{p}<0.001$ versus control group; the data are presented as the means \pm S.E.M. \# $-\mathrm{p}<0.05$, \#\# $\mathrm{p}<0.01$ versus $\mathrm{ROT}+\mathrm{DMCO}$ group; $\alpha-\mathrm{p}<0.05$ in comparison with the $\mathrm{ROT}+2.3$-DP $0.5 \mathrm{mg} / \mathrm{kg}$ group. 
Under the effect of 2.3 DP no significant changes were obtained in the group ROT+2.3DP $2 \mathrm{mg} / \mathrm{kg}$.

In ROT treatment the rats significantly reduced the level of bile secretion as evidenced by a decrease in bile volume in the group on average by $33.8 \%(p<0.001)$. In rats of the $\mathrm{ROT}+\mathrm{DMSO}$ and ROT+2.3 DP 2.0 groups, bile flow was lower on average by $24.3 \%$ $(\mathrm{p}<0.01)$ than in control rats. In 2.3DP-treated rats $(0.5$ and $1 \mathrm{mg} / \mathrm{kg})$, the value of the bile flow did not differ from the control level (Table 2).

The biochemical analysis of bile showed that bile levels of TCA and GCA in ROT-treated rats were decreased by $18.2 \%(\mathrm{p}<0.001)$ and by $17.0 \%(\mathrm{p}<0.01)$, respectively as compared with vehicle group. In ROT+2.3-DP group, the levels of TCA in the bile were found to be significantly increased following drug administration for 28 days. Without applying 2.3-DP, the concentration of TCA in bile did not return to normal level reaching $84 \%$ of the control. On the contrary, administration of 2.3-DP did not affect the reduced content of GCA. Meanwhile,

Table 1. The effects of 2.3-DP on ROT-induced decrease in liver tissue oxygenation

\begin{tabular}{l|c}
\multicolumn{1}{c|}{ Animals group } & $\begin{array}{c}\text { Liver oxygen } \\
\text { consumption (x100) }\end{array}$ \\
\hline Control & $1.92 \pm 0.03$ \\
\hline ROT $2 \mathrm{mg} / \mathrm{kg}$ & $1.27 \pm 0.08^{* * *}$ \\
\hline ROT $2 \mathrm{mg} / \mathrm{kg}+1 \%$ DMSO & $1.41 \pm 0.12^{\text {*** }}$ \\
\hline ROT $2 \mathrm{mg} / \mathrm{kg}+2.3-\mathrm{DP} 0.5 \mathrm{mg} / \mathrm{kg}$ & $1.96 \pm 0.15^{\# \#}$ \\
\hline ROT $2 \mathrm{mg} / \mathrm{kg}+2.3-\mathrm{DP} 1 \mathrm{mg} / \mathrm{kg}$ & $1.98 \pm 0.17^{\# \#}$ \\
\hline ROT $2 \mathrm{mg} / \mathrm{kg}+2.3-\mathrm{DP} 2 \mathrm{mg} / \mathrm{kg}$ & $1.5 \pm 0.18$ \\
\hline
\end{tabular}

The data are presented as the means \pm S.E.M. Different lettes: $\mathrm{p}<0.01) ; n=9$. $* * * \ldots \mathrm{p}<0.001$ compared with the control group; \#\#-p $<0.01$ compared with the ROT+DMSO group. the concentration of TCDCA+TDCA in rat bile did not change in all experimental groups in comparison with control data (Table 3 ) whereas the concentrations of both GCDCA+GDCA and CA increased by $19.5 \%(\mathrm{p}<0.05)$ and by $18.8 \%(\mathrm{p}<0.05)$, respectively. In 2.3-DP-treated group the content of GCDCA+GDCA remained elevated in the ROT+2.3-DP $2 \mathrm{mg} / \mathrm{kg}$ group, but CA concentration recovered to the control level in all 2.3-DP-treated groups of rats.

Under the effect of ROT, the content of CDCA+DCA in bile was modified. This index was significantly increased as compared with control data. The stimulatory effect of ROT on CDCA+DCA level in rat bile was about $58.3 \%$ $(\mathrm{p}<0.001)$ when compared with vehicle (control) group. After the application of 2.3-DP, this indicator completely returned to the control level only in the ROT+2.3-DP $0.5 \mathrm{mg} / \mathrm{kg}$ group (Table 3 ).

The current data revealed that the total BAs concentrations in ROT and ROT+DMSO groups were less as compared with control data by $9.7 \%(\mathrm{p}<0.05)$ and by $9.1 \%(\mathrm{p}<0.01)$, respectively. Under the influence of 2.3-DP at

Table 2. The influence of 2.3-DP on bile flow in rats $(\mu \mathrm{l} / \mathrm{g})$ with ROT-induced PD

\begin{tabular}{l|c}
\hline \multicolumn{1}{c|}{ Animal group } & $\begin{array}{c}\text { The volume of } \\
\text { secreted bile }\end{array}$ \\
\hline Control & $2.7 \pm 0.08$ \\
\hline ROT $2 \mathrm{mg} / \mathrm{kg}$ & $1.8 \pm 0.08^{* * *}$ \\
\hline ROT $2 \mathrm{mg} / \mathrm{kg}+1 \%$ DMSO & $2.1 \pm 0.1^{* * *}$ \\
\hline ROT $2 \mathrm{mg} / \mathrm{kg}+2.3-\mathrm{DP} 0.5 \mathrm{mg} / \mathrm{kg}$ & $2.4 \pm 0.09^{\# \# \#}$ \\
\hline ROT $2 \mathrm{mg} / \mathrm{kg}+2.3-\mathrm{DP} 1 \mathrm{mg} / \mathrm{kg}$ & $2.3 \pm 0.08^{\# \#}$ \\
\hline ROT $2 \mathrm{mg} / \mathrm{kg}+2.3-\mathrm{DP} 2 \mathrm{mg} / \mathrm{kg}$ & $2.1 \pm 0.07^{* *}$ \\
\hline
\end{tabular}

The data are presented as the means \pm S.E.M. Different lettes: $\mathrm{p}<0.01 ; n=8$. ** $-\mathrm{p}<0.01 ; * * *-\mathrm{p}<0.001$ compared with the control group; ${ }^{\#}-\mathrm{p}<0.001$ compared with the ROT group. 
V. P. Khilya, I. P. Yanchuk, L. Ya. Shtanova et al.

Table 3. The effect of 2.3-DP on the concentration of BAs in the bile of rats with PD

\begin{tabular}{|c|c|c|c|c|c|c|}
\hline Animal group & $\begin{array}{c}\mathrm{TCA} \\
\mathrm{mg} / \%\end{array}$ & $\begin{array}{c}\text { TCDCA+TDCA } \\
\mathrm{mg} / \%\end{array}$ & $\begin{array}{l}\mathrm{GCA} \\
\mathrm{mg} / \%\end{array}$ & $\begin{array}{c}\text { GCDCA+GDCA } \\
\mathrm{mg} / \%\end{array}$ & $\begin{array}{c}\mathrm{CA} \\
\mathrm{mg} / \%\end{array}$ & $\begin{array}{c}\mathrm{CDCA}+\mathrm{DCA} \\
\mathrm{mg} / \%\end{array}$ \\
\hline Control & $219.2 \pm 5.2$ & $106.7 \pm 3.7$ & $121.2 \pm 3.8$ & $22.5 \pm 1.05$ & $15.4 \pm 0.7$ & $13.2 \pm 0.5$ \\
\hline ROT $2 \mathrm{mg} / \mathrm{kg}$ & $\begin{array}{l}179.3 \pm 6.0 \\
* * *\end{array}$ & $117.3 \pm 3.1$ & $\begin{array}{c}107.5 \pm 2.7 \\
* *\end{array}$ & $26.9 \pm 0.9^{*}$ & $\underset{* * *}{18.3 \pm 0.8}$ & $20.9 \pm 0.4$ \\
\hline $\begin{array}{l}\text { ROT } 2 \mathrm{mg} / \mathrm{kg}+1 \% \\
\text { DMSO }\end{array}$ & $\underset{* * *}{184.0 \pm 5.1}$ & $\begin{array}{c}97.1 \pm 2.8 \\
\ldots \#\end{array}$ & $\underset{* * *}{95.9 \pm 2.7}$ & $21.4 \pm 1.0$ & $\begin{array}{c}17.5 \pm 0.55 \\
*\end{array}$ & $\begin{array}{c}16.5 \pm 0.4 \\
* * *, \#\end{array}$ \\
\hline $\begin{array}{l}\text { ROT } 2 \mathrm{mg} / \mathrm{kg} \\
+2.3-\mathrm{DP} 0.5 \mathrm{mg} / \mathrm{kg} \\
\end{array}$ & $\begin{array}{c}219.7 \pm 5.3 \\
\# \#, \alpha \alpha \alpha\end{array}$ & $\begin{array}{c}97.3 \pm 2.9 \\
\# \#\end{array}$ & $\begin{array}{c}104.2 \pm 3.3 \\
* *\end{array}$ & $23.2 \pm 1.0$ & $\begin{array}{c}15.4 \pm 0.4 \\
\#\end{array}$ & $\underset{13.0 \pm 0.6}{\# \#}$ \\
\hline $\begin{array}{l}\text { ROT } 2 \mathrm{mg} / \mathrm{kg}+2.3-\mathrm{DP} \\
1 \mathrm{mg} / \mathrm{kg}\end{array}$ & $\begin{array}{c}217.7 \pm 3.7 \\
\# \#, \alpha \alpha \alpha\end{array}$ & $\begin{array}{c}111.8 \pm 3.0 \\
\alpha, £\end{array}$ & $\underset{* * *}{92.5 \pm 3.6}$ & $24.2 \pm 1.2$ & $16.3 \pm 1.0$ & $\begin{array}{c}10.8 \pm 0.7 * \\
\ldots\end{array}$ \\
\hline $\begin{array}{l}\text { ROT } 2 \mathrm{mg} / \mathrm{kg}+2.3-\mathrm{DP} \\
2 \mathrm{mg} / \mathrm{kg}\end{array}$ & $\begin{array}{c}204.1 \pm 4.5 \\
\# \#\end{array}$ & $\begin{array}{c}99.8 \pm 3.3 \\
\ldots\end{array}$ & $\begin{array}{l}99.7 \pm 1.9 \\
* * *\end{array}$ & $\begin{array}{l}27.5 \pm 0.9 \\
*\end{array}$ & $\begin{array}{c}16.8 \pm 0.6 \\
\text { \#\# }\end{array}$ & $\begin{array}{c}11.2 \pm 0.6 \\
*, \ldots \#\end{array}$ \\
\hline
\end{tabular}

Values are presented as the means \pm S.E.M. ${ }^{*}-\mathrm{p}<0.05,{ }^{* *}-\mathrm{p}<0.01{ }^{* * *}-\mathrm{p}<0.001$ vs. the vehicle control group; ${ }^{*}-$ $\mathrm{p}<0.05$, \# $-\mathrm{p}<0.01$, \#\# $-\mathrm{p}<0.001$ vs. the ROT group; ${ }^{\alpha}-\mathrm{p}<0.05$, ${ }^{\alpha \alpha \alpha}-\mathrm{p}<0.001$ vs. the ROT+ $1 \%$ DMSO group; $£-\mathrm{p}<0.05$ vs. the ROT $+2.3-\mathrm{DP} 0.5 \mathrm{mg} / \mathrm{kg}$ group.

doses of 0.5 and $1 \mathrm{mg} / \mathrm{kg}$, the concentration of total BAs were equal to the control level. Similar differences were observed in the changes of total conjugated BAs content in the bile of rats with PD. This index was decreased by $12.2 \%(\mathrm{p}<0.001)$ and by $17.3 \%(\mathrm{p}<0.001)$ in both ROT and ROT+DMSO groups, respectively. ROT-treated rats exhibited an increase in biliary total conjugated BAs level relatively to the control data after applying 2.3-DP doses of 0.5 and $1 \mathrm{mg} / \mathrm{kg}$. In the ROT+DMSO and ROT+2.3 DP groups, the bile concentration of total conjugated BAs remained lower than the control indicators by $17.3 \%(\mathrm{p}<0.001)$ and by $10.6 \%(\mathrm{p}<0.01)$, respectively. The content of total free BAs, in response to ROT administration, was higher than in the control rats by $31.3 \%(\mathrm{p}<0.01)$. On the contrary, after 2.3 DP-treatment the total free BAs content diminished to the initial level in all experimental groups. In ROT+DMSO group when compared with ROT-treated rats no statistical difference was observed. Accordingly, the ratio between total conjugated and total free BAs diminished in this groups of rats by $26.7 \%$ $(p<0.01)$ and by $29.2 \%(p<0.001)$, respectively compared to control values (Table 4).

The obtained results indicate that in rats with ROT model of PD the statistically significant decrease of the content of total trihydroxycholanic BAs was $12.2 \%(p<0.001)$, and the level of total dihydroxycholanic BAs, on the contrary, increased by $16.2 \%(\mathrm{p}<0.01)$. Accordingly, the coefficient of hydroxylation decreased by $16 \%(p<0.001)$. All rats of the ROT + DMSO group exhibited somewhat reduced bile concentration (by $16.5 \%$, p $<0.001$ ) of total trihydroxycholanic BAs. The similar result was observed in $\mathrm{ROT}+2.3-\mathrm{DP} 0.5$ and ROT+2.3-DP 1.0 groups except for ROT+2.3DP 2.0 group, the indicators of which were as in the control group. Conversely, the content of dihydroxycholanic BAs in the bile was restored to [the] control level in all groups of rats with modeled PD both treated by $1 \%$ DMSO and by 2.3-DP in different doses. Thus, 
The evaluation of 2.3-diazepine influence on liver in rats with a rotenone model of Parkinson's disease

Table 4. Changes in the concentration of total, total conjugated and total free BAs in the bile of rats with ROT-induced PD treated by 2.3-DP

\begin{tabular}{|c|c|c|c|c|}
\hline Animal group & Total BAs mg/\% & $\begin{array}{l}\text { Total conjugated } \\
\text { BAs } \mathrm{mg} / \%\end{array}$ & Total free BAs mg/\% & $\begin{array}{c}\text { Ratio between total } \\
\text { conjugated and free BAs }\end{array}$ \\
\hline Control & $511.3 \pm 9.2$ & $482.0 \pm 8.7$ & $29.4 \pm 1.0$ & $16.1 \pm 0.7$ \\
\hline ROT $2 \mathrm{mg} / \mathrm{kg}$ & $472.5 \pm 12.9^{*}$ & $423.2 \pm 10.7^{* * *}$ & $38.6 \pm 0.8^{* *}$ & $11.5 \pm 0.6^{* * *}$ \\
\hline ROT $2 \mathrm{mg} / \mathrm{kg}+1 \%$ DMSO & $432.5 \pm 7.5^{* * *}$ & $398.6 \pm 7.7^{* * *}$ & $33.9 \pm 0.3^{* * *}$ & $11.8 \pm 0.3^{* * *}$ \\
\hline ROT $2 \mathrm{mg} / \mathrm{kg}+2.3-\mathrm{DP} 0.5 \mathrm{mg} / \mathrm{kg}$ & $476.5 \pm 5.7^{\alpha}$ & $448.1 \pm 5.5^{\alpha \alpha}$ & $28.4 \pm 0.7^{\# \# \#, \alpha \alpha \alpha}$ & $15.2 \pm 0.4^{\# \# \#, \alpha \alpha \alpha}$ \\
\hline ROT $2 \mathrm{mg} / \mathrm{kg}+2.3-\mathrm{DP} 1 \mathrm{mg} / \mathrm{kg}$ & $473.4 \pm 9.4^{\alpha}$ & $446.2 \pm 8.7^{\alpha \alpha}$ & $27.2 \pm 0.8^{\# \# \#, \alpha \alpha \alpha}$ & $15.8 \pm 0.45^{\# \#, \alpha \alpha}$ \\
\hline ROT $2 \mathrm{mg} / \mathrm{kg}+2.3-\mathrm{DP} 2 \mathrm{mg} / \mathrm{kg}$ & $459.1 \pm 8.8^{* *}$ & $431.1 \pm 8.7^{* *}$ & $28.0 \pm 0.45^{\# \# \#, \alpha \alpha \alpha}$ & $15.4 \pm 0.3^{\# \# \#, \alpha \alpha \alpha}$ \\
\hline
\end{tabular}

The data are presented as the means \pm S.E.M. Different symbols: $* \ldots \mathrm{p}<0.05 ; * * \ldots \mathrm{p}<0.01 ; * * * \ldots \mathrm{p}<0.001$ as compared with control rats; \#-p $<0.05$, \#\#- $\mathrm{p}<0.01$, \#\#\#- $\mathrm{p}<0.001$ relative to ROT+DMSO group; ${ }^{\alpha}-\mathrm{p}<0.05, \alpha-\mathrm{p}<0.01$, $\alpha \alpha \ldots-\mathrm{p}<0.001$ vs. the ROT+DMSO group. Secreted bile was collected during 1 hour of the experiment.

the ratio between total trihydroxycholanic and total dihydroxycholanic BAs in these groups of rats also corresponded to the control values (Table 5).

Discussion. PD is accompanied not only by motor disorders, but also by non-motor symptoms, such as weight loss, constipation, loss of the sense of smell, sleep disturbances, cognitive deficits and depression [4]. Available diagnostic approaches still lead to a high proportion of false diagnoses, in particular, at the early stages of PD, so biochemical markers are required to inform the pathogenesis of parkinsonism. Here, we applied the thin layer chromatography method to determine the profiles of bile metabolites. Characteristics of the metabolites indicate perturbations in the BAs metabolism in PD, which underscores the power of metabolomic approaches.

ROT, a mitochondrial complex I inhibitor, was reported to reproduce a number of neuropathological features of $\mathrm{PD}$, including loss of dopaminergic neurons $[6,8]$. We predicted that this substance may induce a significant inhibition of LTR. Indeed, in the present study, ROT application resulted in a decreased coefficient of oxygen consumption by the liver tissue by $34.3 \%$. 2.3-DP in doses of 0.5 and $1 \mathrm{mg} / \mathrm{kg}$ completely restored this index in rats with experimental model of PD. These

Table 5. The ratio between total trihydroxycholanic and total dihydroxycholanic BAs within bile of rats with PD under the influence of 2.3-DP

\begin{tabular}{l|c|c|c}
\hline \multicolumn{1}{c|}{ Animal group } & Total trihydroxycholanic BAs, mg/\% & Total dihydroxycholanic BAs, mg/\% & Hydroxylation factor \\
\hline Control & $356.1 \pm 9.6$ & $142.2 \pm 4.3$ & $2.5 \pm 0.03$ \\
\hline ROT 2 mg / kg & $307.2 \pm 9.2^{* * *}$ & $165.3 \pm 4.7^{* *}$ & $1.86 \pm 0.06^{* * *}$ \\
\hline ROT +1 \% DMSO & $297.35 \pm 6.5^{* * *}$ & $135.2 \pm 4.6^{\# \#}$ & $2.2 \pm 0.08^{\# \#}$ \\
\hline ROT+2.3-DP 0.5 mg/kg & $324.5 \pm 5.5^{*}$ & $133.5 \pm 2.9$ & $2.4 \pm 0.06^{\# \#}$ \\
\hline Rot + 2.3-DP 1.0 mg kg & $312.2 \pm 4.1^{* * *}$ & $146.8 \pm 3.5$ & $2.3 \pm 0.08^{\# \#}$ \\
\hline Rot + 2.3-DP 2 mg kg & $320.7 \pm 4.3$ & $138.5 \pm 4.1^{\# \#}$ & $2.2 \pm 0.04^{\# \#}$ \\
\hline
\end{tabular}

Means \pm S.E.M. * $-\mathrm{p}<0.05 ; * *-\mathrm{p}<0.01 ; * * *-\mathrm{p}<0.001$ as compared with control group; \#\#-p $<0.01$ as compared with ROT group. 
results suggest that the LTR is an adequate indicator in the drug effectiveness research that may be involved in the correction of liver functions disturbed by PD. In rats with PD induced by ROT, a disturbance in the functions of hepatocyte mitochondria presumably takes place, which resulted in the reduction of the intensity of tissue respiration and oxygen dependent biosynthetic processes in the liver. Thus, on the one hand the volume of produced bile decreased, the conjugation of CA with the amino acids taurine and glycine reduced (the conjugation factor reduced by $29.2 \%$ ), but on the other hand, the portion of acidic pathway in the biosynthesis of BAs increased, enhancing the hydrophobicity of BAs pool. Our results demonstrated that 2.3DP protects against ROT-induced disorders of liver functions in rats with $\mathrm{PD}$ promoting the conjugation of CA with taurine to increase the concentration of TCA. In the presented study, the metabolic changes in the bile of the rats with ROT-simulated PD, were mainly related to the functional state of hepatocyte mitochondria as well as the exchange of BAs. Our results demonstrated that in the rats with PD the total secreted bile volume during overall time of the experiment decreased by $33 \%$ compared to the control subjects. The animals with PD treated by 2.3-DP, exhibited improved bile flow.

The bile formation is a unique function of the liver which is vital for survival of the organism. BAs, as well as their salts, determine the basic properties of bile as a digestive secretion. The intensity of bile secretion is closely related to LTR. As previously has been shown, the reduction in the oxygenation of the liver tissue steadily leads to a decrease in bile volu- me, formed for a certain period of time. It was concluded that the hepatic tissue oxygenation affects hepatic energy metabolism, thus modifying the rate of bile flow in the liver [18]. The unique detergent properties of BAs are essential for the digestion and absorption of hydrophobic nutrients in the small intestine, including dietary fats, fat-soluble vitamins. They also modulate biliary and lipid secretion, regulate the activity of key enzymes involved in the cholesterol homeostasis and prevent cholesterol precipitation [19]. Taking into account the regulatory importance of bile and BAs, we can assume that disorders in both the formation of bile flow and the exchange of BAs may cause a derangement of many complex physiological and biochemical processes in the body. To assess the functional state of the liver, namely the quality of secreted bile, the ratio between individual groups of BAs is important. Therefore, the ratio between total BAs conjugated with amino acids taurine and glycine and total free BAs, the so-called conjugation factor, was studied as well as the ratio between bile trihydro- and dihydrocholates. The findings of this work showed that ROT with long-term (during 28 days) administration significantly reduced the rate of conjugation of CA with glycine $(11.3 \%)$, and especially with taurine (by $18.2 \%$ ), whereas the concentration of free CA within bile increased (by $19.0 \%$ ). As a result, the rate of total conjugated BAs significantly decreased and the number of total free BAs, on the contrary, increased.

The results of our experiments agree with the findings of Govorukha et al. [20]. They found that liver tissue hypoxia caused by various methods, increased the level of free CA 
in bile. These data confirm the inhibitory effect of ROT on the activity of enzymes that provide conjugation of free CA with amino acids. Under the influence of 2.3-DP in doses of 0.5 and $1 \mathrm{mg} / \mathrm{kg}$, the bile content of TCA returned to the control levels. On the contrary, the bile content of GCA in all groups of animals remained lower than in the control group. Both amino acids taurine and glycine, interact with CoA-ether of the corresponding BA during conjugation. The catalysts of this reaction are microsomal CoA-ligase and cytosolic $\mathrm{N}$-acetyltransferase, which operate with the energy consumption and in the presence of $\mathrm{NAD}, \mathrm{AMF}, \mathrm{Mg}^{2+}, \mathrm{CoA}$. The energy deficit in the cell inhibits the conjugation of CA with amino acids. 2.3-DP improved the conjugation of free CA with taurine in ROT-treated rats, probably affecting one of the components of this complex process. Concurrently with the above-mentioned events, in the bile of rats with PD, the level of free CDCA+DCA increased markedly (by $58.3 \%$ ) with a partial enhance in their conjugation with glycine. The tested drug also improved this parameter in all 2.3-DP-treated groups of rats, reducing it to the control level. The reduction of conjugation factor in ROT-treated group in general indicates a markedly decrease (by $29.3 \%$ ) in the activity of enzymes involved in this process. Under the effect of 2.3-DP, this index was completely restored in rats with a ROT model of PD.

Decreased BAs secretion leads to defective micellar solubilization of dietary lipids, and this contributes to lipid malabsorption in these patients. The ability of the bile to emulsify the fats and promote their absorption in the intestine depends on the content of the conjugated
BAs [21]. Based on the latter, it can be assumed that 2.3-DP improves these properties of bile. Noteworthy, in addition to the abovementioned we also found that the ROT reduced the content of trihydroxycholanic BAs, but caused an increase in the level of dihydroxycholanic BAs. The ratio of trihydroxy- to dihydroxycholanic BAs indicates an increase of the role of the "alternative (acidic) pathway" in the biosynthesis of BAs in rats with PD. This synthesis is carried out with the participation of mitochondrial enzymes and is confirmed by a significant increase in bile levels of CDCA and DCA. As is known, BAs are formed by hepatocytes with cholesterol in two pathways: neutral (DCA and CDCA in equal parts) and acidic (predominantly CDCA). The classic pathway involving cholesterol $7 \alpha$-hydroxylase is the major pathway in BAs biosynthesis because its contribution to total BAs synthesis is $\sim 90 \%$ in humans and $\sim 75 \%$ in mice [22]. The ratio between these components of the bile is determined as the coefficient of hydroxylation. This factor shows both the hydrophobicity of BAs pool and the degree of emulsification of fats in the duodenum. According to the obtained results, the coefficient of hydroxylation of BAs was significantly decreased in rats with PD however, 2.3-DP improved this rate. On the other hand noteworthy, the hydroxylation factor returned to the control level also in the group of rats, treated with $1 \%$ DMSO solution only. Consequently, the using of 2.3-DP was not of fundamental importance in this case, since the body had enough resources for providing homeostasis. Recently, Rosa A, et al. have shown in mice that some BAs, in particular tauroursodeoxycholic acid, act as mitochondrial sta- 
bilizer and anti-apoptotic agent in a number of models of neurodegenerative diseases, including PD. This substance prevented a decrease of dopaminergic fibers and ATP levels, mitochondrial dysfunction and neuroinflammation [23].

In our study we observed that ROT-treated rats showed a tendency to weight loss and increased mortality rate. Possible causes related to this decline in body weight could be caused to a gastrointestinal dysfunction in PD [24], in particular with a delay in gastric emptying and the damage to gastrointestinal neurons, occurred during ROT intoxication [25]. We also observed that ROT-treated animals administered with 2.3-DP were less prone to lose weight and to die, arguing in favor of the protective effects of tested drug.

Earlier it was found that severe defects in the complex I activity induce mitochondria depolarization and $\mathrm{Ca}^{2+}$ disregulation [26]. The excessive mitochondrial $\mathrm{Ca}^{2+}$ uptake can cause non-selective permeabilization of the inner mitochondrial membrane possibly leading to swelling the mitochondria and dissipation of the membrane potential from massive proton leakage. Fonseca-Fonseca LA and co-authors support this mechanism. They found that mitochondria isolated from brain of rats with PD, induced by ROT, spontaneously lost their membrane potential and were more prone to membrane permeability/swelling than the vehicle group [10]. Here we observed a decrease in the intensity of LTR in rats following ROT administration. The improvement of this indicator after application of 2.3-DP shows the restoration of mitochondrial functions in hepatocytes of the liver under the influence of the tested substance. The improvement of the liver choleretic function, the biochemical composition of bile, which we observed in our experiments, also indicates an increase in the energy status of hepatocytes under the influence of 2.3-DP.

Conclusions Our results demonstrate that 2.3-DP protects against ROT-induced disorders in PD by promoting the LTR and especially conjugation of CA with taurine to enhance bile concentration of TCA. Additionally, the tested drug normalizes the ratio between the acidic and the neutral pathways in the biosynthesis of BAs, attenuating the hydrophobicity of bile. Probably, the improvement of liver secretory function in rats with PD, which we observed, is associated with the restoration of energy homeostasis of the liver under the influence of 2.3-DP. Considering the complexity of molecular and neurological systems, further studies are required to characterize 2.3-DP as a new possible drug against $\mathrm{PD}$.

\section{REFERENCES}

1. Kalia LV, Lang AE. Parkinson's disease. Lancet. 2015;386(9996):896-912.

2. Coppedè F. Genetics and epigenetics of Parkinson's disease. ScientificWorldJournal. 2012;2012:489830.

3. Park JS, Davis RL, Sue CM. Mitochondrial Dysfunction in Parkinson's Disease: New Mechanistic Insights and Therapeutic Perspectives. Curr Neurol Neurosci Rep. 2018;18(5):21.

4. Baig F, Lawton M, Rolinski M, Ruffmann C, Nithi K, Evetts SG, Fernandes HR, Ben-Shlomo Y, Hu MT. Delineating nonmotor symptoms in early Parkinson's disease and first-degree relatives. Mov Disord. 2015;30(13):1759-66.

5. Zhao H, Wang C, Zhao N, Li W, Yang Z, Liu X, Le W, Zhang $X$. Potential biomarkers of Parkinson's disease revealed by plasma metabolic profiling. J Chromatogr B Analyt Technol Biomed Life Sci. 2018;1081-1082:101-108. 
6. Cannon JR, Greenamyre JT. Gene-environment interactions in Parkinson's disease: specific evidence in humans and mammalian models. Neurobiol Dis. 2013;57:38-46.

7. Sherer TB, Betarbet R, Testa CM, Seo BB, Richardson JR, Kim JH, Miller GW, Yagi T, Matsuno-Yagi A, Greenamyre JT. Mechanism of toxicity in rotenone models of Parkinson's disease. J Neurosci. 2003; 23(34):10756-64.

8. Betarbet R, Sherer TB, MacKenzie G, Garcia-Osuna M, Panov AV, Greenamyre JT. Chronic systemic pesticide exposure reproduces features of Parkinson's disease. Nat Neurosci. 2000;3(12):1301-6.

9. Jenner P. A2A antagonists as novel non-dopaminergic therapy for motor dysfunction in PD. Neurology. 2003;61(11 Suppl 6):S32-8.

10. Fonseca-Fonseca LA, Wong-Guerra M, RamírezSánchez J, Montano-Peguero Y, Padrón Yaquis AS, Rodríguez AM, da Silva VDA, Costa SL, PardoAndreu GL, Núñez-Figueredo Y. JM-20, a novel hybrid molecule, protects against rotenone-induced neurotoxicity in experimental model of Parkinson's disease. Neurosci Lett. 2019;690:29-35.

11. Khabarov KM, Kharaneko OI, Bogza SL. 2,3 Benzodiazepine-1-thione in the synthesis of substituted and hetero-annelated 2,3-benzodiazepines. Chem Heterocycl Compd. 2009; 45(4): 468-74.

12. Gallagher D, Belmonte D, Deurenberg P, Wang Z, Krasnow N, Pi-Sunyer FX, Heymsfield SB. Organtissue mass measurement allows modeling of REE and metabolically active tissue mass. Am J Physiol. 1998;275(2):E249-58.

13. Chang YT, Luo XG, Ren $Y$. Behavior alteration and damage of dopaminergic neurons of substantia nigra caused by rotenone in rats. Jiepouxue Yanjiu Jingzhan. 2011; 7: 60-2.

14. Bures J, Burešová O, Huston JP. Techniques and Basic Experiments for the Study of Brain and Behavior. Elsevier. 1976; 37-89.

15. Berezovsky VA. Oxygen tension in animal and human tissues. Kyiv, Naukova dumka, 1975; 230p.

16. Tsybenko VA, Egorova LS, Mikhaĭlova NV, Zhakhalova LA, Dubileı TA. [Neurogenic control of oxidative metabolism in the liver]. Fiziol Zh SSSR Im I M Sechenova. 1988;74(5):737-45. .
17. Ghazaee SP, Gorenko ZA, Karbovska LS, Veselsky SP, Yanchuk PI, Makarchuk MY. Desmopressin stimulates bile secretion in anesthetized rats. Gen Physiol Biophys. 2010;29(2):151-9.

18. Matsumura T, Sato N, Kawano S, Hijioka T, Eguchi H, Kamada T. Effect of hepatic blood oxygenation on bile secretion in rats. Adv Exp Med Biol. 1988;222:585-9.

19. Claudel T, Staels B, Kuipers F. The Farnesoid X receptor: a molecular link between bile acid and lipid and glucose metabolism. Arterioscler Thromb Vasc Biol. 2005;25(10):2020-30. .

20. Hovorukha TM, Nazarenko AI, Zhalilo LI, Fil' HB, Baban VM, Seredenko MM. [Disturbances in biliary secretion during tissue hypoxia and attempts at their corrections]. Fiziol Zh. 2002; 48(1):35-40.

21. Hofmann AF, Mysels KJ. Bile acid solubility and precipitation in vitro and in vivo: the role of conjugation, pH, and Ca2+ ions. J Lipid Res. 1992;33(5): 617-26. Review.

22. Russell $D W$. The enzymes, regulation, and genetics of bile acid synthesis. Annu Rev Biochem. 2003;72:137-74. Review.

23. Rosa AI, Duarte-Silva S, Silva-Fernandes A, Nunes MJ, Carvalho AN, Rodrigues E, Gama MJ, Rodrigues CMP, Maciel P, Castro-Caldas M. Tauroursodeoxycholic Acid Improves Motor Symptoms in a Mouse Model of Parkinson's Disease. $\mathrm{Mol}$ Neurobiol. 2018;55(12):9139-9155.

24. Pfeiffer RF. Gastrointestinal Dysfunction in Parkinson's Disease. Curr Treat Options Neurol. 2018; 20(12):54.

25. Morais LH, Lima MM, Martynhak BJ, Santiago R, Takahashi TT, Ariza D, Barbiero JK, Andreatini R, Vital MA. Characterization of motor, depressive-like and neurochemical alterations induced by a shortterm rotenone administration. Pharmacol Rep. 2012;64(5):1081-90.

26. Uversky VN. Neurotoxicant-induced animal models of Parkinson's disease: understanding the role of rotenone, maneb and paraquat in neurodegeneration. Cell Tissue Res. 2004;318(1):225-41. 
Оцінка впливу 2.3-діазепіну на тканинне дихання і зовнішньосекреторну функцію печінки щурів 3 ротеноновою моделлю хвороби Паркінсона

В. П. Хиля, П. І. Янчук, Л. Я. Штанова, С. П. Весельський, Т. В. Вовкун, О. В. Цимбалюк, В. С. Москвіна, О. В. Шаблікіна, С. Л. Богза.

Хвороба Паркінсона (ХП) - це прогресуюче нейродегенеративне захворювання, що характеризується втратою дофамінергічних нейронів у субстанції nigra pars compacta. Причини ХП не повністю зрозумілі, проте, все більше даних свідчить про порушення дихальної функції мітохондрій і нестачі енергії в клітинах. Мета. Вивчити вплив 2.3-діазепіну (2.3-ДП), нового похідного бензодіазепіну, на тканинне дихання печінки (ТДП) і енергетично залежні процеси продукції жовчі й жовчних кислот (ЖК) у щурів з ХП, модельованою ротеноном (РОТ). Методи. ХП була викликана у щурів внутрішньоочеревинними ін'єкціями РОТ. ТДП (інтенсивність поглинання кисню) оцінювали за допомогою полярографа LP-9 (Чеська Республіка). Секретовану жовч збирали протягом 1 години експерименту через поліетиленовий катетер, вставлений в загальний жовчний протік. ЖК розділяли методом тонкошарової хроматографії. Результати. РОТ зменшував коефіцієнт споживання $\mathrm{O}_{2}$ в печінці на $34 \%(\mathrm{p}<0.001)$, знижував відтік жовчі на $33.8 \%(\mathrm{p}<0.001)$ і порушував кон'югацію холевої кислоти з амінокислотами таурином і гліцином, зменшуючи коефіцієнт кон'югації на $29.2 \%(\mathrm{p}<0.001)$. РОТ також збільшував на $25.6 \%(\mathrm{p}<0.001)$ частку кислого шляху в біосинтезі ЖК. Застосування 2.3-ДП призводило до повного відновлення ТДП, або часткового - відтоку жовчі, концентрацій ЖК і їх співвідношення в жовчі щурів з ХП. Висновок. 2.3-ДП істотно впливає на функцію паренхіми печінки у щурів з РОТ моделлю ХП. Цей препарат відновлює ТДП, покращує відтік жовчі і помітно поліпшує її хімічний склад, порушений при застосуванні РОТ.

Кл ю ч о в і с л о в а: хвороба Паркінсона, 2.3-діазепін, тканинне дихання печінки, відтік жовчі, жовчні кислоти.

\section{Оценка влияния 2,3-диазепина на тканевое дыхание и внешнесекреторную функцию печени крыс с ротеноновой моделью болезни Паркинсона}

В. П. Хиля, П. И. Янчук, Л. Я. Штанова, С. П. Весельский, Т. В. Вовкун, О. В. Цимбалюк, В. С. Москвина, О. В. Шабликина, С. Л. Богза.

Болезнь Паркинсона (БП) - это прогрессирующее нейродегенеративное заболевание, характеризующееся потерей дофаминергических нейронов в субстанции nigra pars compacta. Причины БП не полностью поняты, тем не менее, все больше данных свидетельствует о нарушении дыхательной функции митохондрий и недостатке энергии в клетках. Цель. Изучить влияние 2.3-диазепина (2.3-ДП), нового производного бензодиазепина, на тканевое дыхание печени (ТДП) и энергетически зависимые процессы продукции желчи и желчных кислот (ЖК) у крыс с БП, моделированной ротеном (РОТ). Методы. БП была вызвана у крыс внутрибрюшинными инъекциями РОТ. ТДП (интенсивность поглощения кислорода) оценивали с помощью полярографа LP-9 (Чешская Республика). Секретированную желчь собирали в течение 1 часа эксперимента через полиэтиленовый катетер, вставленный в общий желчный проток. ЖК были разделены методом тонкослойной хроматографии. Результаты. РОТ уменьшал коэффициент потребления $\mathrm{O}_{2}$ в печени на $34 \%$ ( $\left.>0.001\right)$, снижал отток желчи на $33.8 \%$ ( $<$ < 0.001$)$ и нарушал конъюгацию холевой кислоты с аминокислотами таурином и глицином, уменьшив коэффициент конъюгации на $29.2 \%(\mathrm{p}<0.001)$. РОТ также увеличивал на $25.6 \%$ (p < 0.001) долю кислого пути в биосинтезе ЖК. Применение 2.3-ДП приводило к полному восстановлению ТДП, или частичному оттока желчи, концентраций ЖК и их соотношения в желчи крыс с БП. Заключение. 2.3-ДП существенно влияет на функцию паренхимы печени у крыс с РОТ моделью БП. Этот препарат восстановил интенсивность ТДП, оттока желчи и заметно улучшил ее химический состав, нарушенный применением РОТ.

Кл юч е в ы е с л о в а: болезнь Паркинсона, 2.3-диазепин, тканевое дыхание печени, отток желчи, желчные кислоты. 